\title{
Effect of Fish Transportation on Haematology Parameters and Bacterial Diseases in Anabas testudineus Fish
}

\author{
Esti Handayani Hardi, Asmir, Catur Agus Pebrianto, Gina Saptiani, Agustina
}

\begin{abstract}
Lab. Microbiology, Department of Aquaculture, Faculty of Fisheries and Marine Science, Mulawarman University, East Kalimantan Indonesia. 2 Lab. of Forest Product Chemistry, Faculty of Forestry, Mulawarman University, East Kalimantan, Indonesia. Corresponding author : E. H. Hardi, Email : estieriyadi2011@gmail.com
\end{abstract}

\begin{abstract}
Esti Handayani Hardi, Asmir, Catur Agus Pebrianto, Gina Saptiani, and Agustina. 2015. Effect of Fish Transportation on Haematology Parameters and Bacterial Diseases in Anabas testudineus Fish. Aquacultura Indonesiana, 16 (2): 73-77. This study was conducted to determine the effect of fish transportation on haematology parameters and the presence of bacterial diseases in Anabas Testudineus fish that was transported from pond cultivation toward Segiri Market. Fish transportation manner was carried out by the fishmonger supposed to influence the fish health condition as well as the presence of bacteria on the fish's body. The sample was 30 fishes from Muara Kaman pond and Segiri Fish Market. Fish health parameters observed were besed on swimming behavior, pathology of organs, haemotology, and inventory of bacterial diseases. The results showed that the samples of fish from the pond cultivation generally exhibited normal conditions of organ anatomy andnormal swimming behavior. On the other side, fishes marketed in the Market Segiri, as much as $60 \%$ of fishes have abnormal swimming behavior, $73 \%$ have pathology on external anatomy, and $53 \%$ fish have abnormalities in organs. Results of the isolation and identification of bacterial diseases can be stated that there were five generalsbacteria e.g.. Aeromonas, Pseudomonas, Staphyllococcus, Streptococcus, and Basillus. Staphyllococcus and Basillus were not found in fish from pond cultivation. The fish health condition collected from pond cultivation was better. It wasjudged from the hemoglobin, hematocrit, total leukocyte and total erythrocyte that were within the normal ranges. While, the fish haematology condition from Segiri Market was generally higher in all parameters indicating the low of health status. Therefore, $t$ it can be concluded that the transportation manner carried out by the wet etching fishmonger affected the occurrence of abnormalities of fish behavior, anatomic pathology of outer and inner organs, the presence of bacterial disease, and the decline in fish health condition.
\end{abstract}

Keywords : Bacterial; Betok fish; Transportation

\section{Introdaction}

Among many species of local fishes in East Kalimantanwhich have good prospects for cultivation, one of those is the betok (Anabas testudineus Bloch). Betok is a fish which has high demand by the public of East Kalimantan and its surroundings because it has a distinctive flavor and tasty meat, so it is easy to find in the major markets in Samarinda. This fish looks more interesting when the condition is still alive, so that the freight transport system (transportation) and shelter from the origin place to the market is very important to keep the betok fish in order to remain in living condition and no change in outside organs anatomy (there are not pathological changes/ulcers/scales off/ exoptalmia).

Betok sold in markets comes from Kota Bangun Segiri.It is harvested from traditional cultivation nor arrested from the ponds (like land) for \pm 3 weeks before it is sold. Fishes were transported in a box with aeration in a very high density ( 5 fishes/L) from Kota Bangun via the Mahakam River to fish markets. Furthermore, the fishes were trasported to Segiri Market by fish traders using stereofom. In the Segiri Market, fishes were displayed and sold at the fish accommodating etching in a container made of wood covered with plastic mats as high as $20 \mathrm{~cm}$ and filled with water as high as $10 \mathrm{~cm}$.

The fishsold in the Market of Segiri often got injured, scales off, bleeding, and even death. Thereby, this condition would influence reducing enthusiasts to buy. Factors caused the fish abnormalities in outside organs have not been known, but presumably those are because of the transportation process from cultivation area/shelter to the market. The fishes were transported in a long distance in simple transportation container.

This research was conducted by taking samples of fishes from an aquaculture/shelter of betok (Kota Bangun) and from fish Market of Segiri. The purpose of the research is to know the 
effect of transportation on fish health condition and the presence of bacterial disease in fish. Helpfully, this research might provide some information to buyers, farmers and fish sellers etching on the health condition of the betok.

\section{Materials and Methods}

\section{Time and Place Research}

The research was done by researcher from October to December 2012 in Aquatic Microbiology Laboratory, Department of Aquaculture, Faculty of Fisheries and Marine Sciences, University of Mulawarman. Fish samples examined were betok (Anabas Testudineus) originating from aquaculture pond area of Muara Kaman and Market of Segiri, Samarinda with length $\pm 25 \mathrm{~cm}$ by 30 individuals.

\section{Bacteria isolation}

Bacterial isolation was conducted by the method of Hardi et al. (2011) from the organs of liver, kidneys, eyes, and brain, on NA medium (MERCK®). The plates were incubated at 28$30^{\circ} \mathrm{C}$ for 24 hours and colonies of bacteria growed were observed after 24 hours.

\section{Characteristic bacteria test}

Characterizations of bacterial isolation were carried out by observing bacterial cell morphology, physical, and biochemical tests of bacteria refers to bacteria identification method of A. hidrophyla (SNI: 2009) which includes Gram staining, motility test, oxidativefermentative test, and catalase test.

\section{Parameters}

symptoms Observation of fish behavior can be done by looking at the swimming patterns (movement in the water column and the movement of the fin), reflex (startle response which is done by fish in the aquarium) and operculum movements (movements open and close in a minute). These observations were made for 5 min of each fish.

observations in Anatomic pathology are done by looking at changes in color, shape, and consistency of the external organs. Besides that, the other organs observed were eyes, liver, and kidneys.

Blood picture observation and measurement of hemoglobin levels used Sahli method with Sahlinometer (Wedemeyer and Yasutake, 1977). Hematocrit used method of Anderson and Siwicki (1995) andtotal leukocyte and total erythrocyte followed the procedures of Braxhall And Daisley (1973).

\section{Results and Discussion}

\section{Fish Behaviour Symptoms}

The observation of behavior symptoms of Betok fish was done in aquaculture pond and Segiri Market as it can be seen in Table 1 .

In table 1it can be seen that the fish samples taken from aquaculture pond. Those look normal. There areonly $13 \%$ of fishes that show signs of abnormality in the form of swimming patterns more aggressive, operculum movements tend to be faster and slower reflexes to shock. Besides that, it shows that the Betok fish coming from aquaculture pond is still in normal conditions be symptomatic behavior.

Table 1. Symptoms behavior betok fish from aquaculture pond and marketed in the Segiri Market

\begin{tabular}{|c|c|c|c|c|c|c|c|c|c|c|c|c|c|c|c|c|}
\hline \multirow{2}{*}{$\begin{array}{c}\text { Perubahan } \\
\text { Change }\end{array}$} & \multirow{2}{*}{$\begin{array}{c}\text { Asal ikan } \\
\text { sampel }\end{array}$} & \multicolumn{15}{|c|}{ Betok Fish sample } \\
\hline & & 1 & 2 & 3 & 4 & 5 & 6 & 7 & 8 & 9 & 10 & 11 & 12 & 13 & 14 & 15 \\
\hline slowly & cultivation & - & - & - & + & - & - & - & + & - & - & - & - & - & - & - \\
\hline swimming & Market & + & - & + & - & + & + & + & + & + & + & + & - & - & - & - \\
\hline $\begin{array}{c}\text { Fast } \\
\text { Operculum }\end{array}$ & cultivation & - & - & - & + & - & - & - & + & - & - & - & - & - & - & - \\
\hline Movement & Market & + & - & + & - & + & + & + & + & + & + & + & - & - & - & - \\
\hline $\begin{array}{c}\text { Slow } \\
\text { reflexes }\end{array}$ & cultivation & - & - & - & + & - & - & - & + & - & - & - & - & - & - & - \\
\hline motion & Market & + & - & + & - & + & + & + & + & + & + & + & - & - & - & - \\
\hline
\end{tabular}

Description :

+ : Experiencing the changing patterns of swimming, operculum movements faster and reflex

-: No change 
The condition of fish comes from Segiri Market is generally inabnormality conditions. They are $60 \%$ of the Betok fish changes in swimming patterns, operculum movements, and reflex movements.

Next, the observation of fish behavior symptoms showed thatswimming patterns of fish derived from Segiri Market tend to be more aggressive, some fishes found swimming oblique, operculum movements and reflex slower than the condition of fish originated from aquaculture or had a shelter.

Transportion and storage systems affect to the behavior of fish. The fish becomes weak due to lack of oxygen supply during transportion and shelter of Betok Fish is sold. Another factor, that can influence the occurrence of abnormalities in Betok Fish, is marketed in the fish Market of Segiri. It is because of the transportion process which uses pickup and high density, The fishes tend to get friction between a fish with another fish. Futhermore, it is also because of the freight container, So the condition of fish becomes weaker.

\section{Pathologycal External Organs}

The outside observations of the organ anatomical pathology of Betok Fish originated from aquaculture / fish shelter and the Market of Segiri as presented in Table 2.

In Table 2 it is explained aboutthe anatomical conditions of Betok Fish coming from aquaculture pond macroscopically. A total of $40 \%$ of the Betok changes in the anatomy of the outside organ, but the changes are visible in the form of red spots on the operculum and fins. Anatomical pathology seemed conspicuous by other normal fish. As the Betok Fish marketed at the Segiri Market there is as much as $73 \%$ of fish samples got anatomical changing in outside organs.

Anatomic pathology of external organ of Betok Fishes originating from Segiri Market with fish originating from aquaculture pond/reservoir is different. Fish from Segiri Market is likely to change in body surface in the form of red spots, flaky scales and sores (Figure 1).

Table 2. Pathology organ anatomy outside the etching fish coming from aquaculture pond and Markets Segiri

\begin{tabular}{ccccccccccccccccc}
\hline $\begin{array}{c}\text { External } \\
\text { organs } \\
\text { pathology }\end{array}$ & $\begin{array}{c}\text { Source of } \\
\text { fish }\end{array}$ & $\mathbf{1}$ & $\mathbf{2}$ & $\mathbf{3}$ & $\mathbf{4}$ & $\mathbf{5}$ & $\mathbf{6}$ & $\mathbf{7}$ & $\mathbf{8}$ & $\mathbf{9}$ & $\mathbf{1 0}$ & $\mathbf{1 1}$ & $\mathbf{1 2}$ & $\mathbf{1 3}$ & $\mathbf{1 4}$ & $\mathbf{1 5}$ \\
\hline $\begin{array}{c}\text { ulcer on } \\
\text { fish body }\end{array}$ & culture & - & - & - & - & - & - & - & - & - & - & - & - & - & - & - \\
& Market & - & - & + & - & - & + & + & + & + & - & + & + & - & - & - \\
\multirow{2}{*}{ Operculum } & culture & - & - & - & + & - & - & - & + & - & - & - & - & - & - & - \\
& Market & - & - & - & - & + & + & + & + & + & + & + & - & - & - & - \\
\multirow{2}{*}{ fins } & culture & - & - & - & - & - & - & - & + & + & + & - & - & - & + & + \\
& Market & + & + & - & - & - & - & + & + & + & + & + & - & - & - & - \\
\multirow{2}{*}{ Eyes } & culture & - & - & - & - & - & - & - & - & - & - & - & - & - & - & - \\
& Market & - & - & - & - & - & + & + & + & + & - & - & - & - & - & - \\
\hline
\end{tabular}

Description :

PA: Pathology

+: Experiencing changes in shape, color and consistency

-: No change

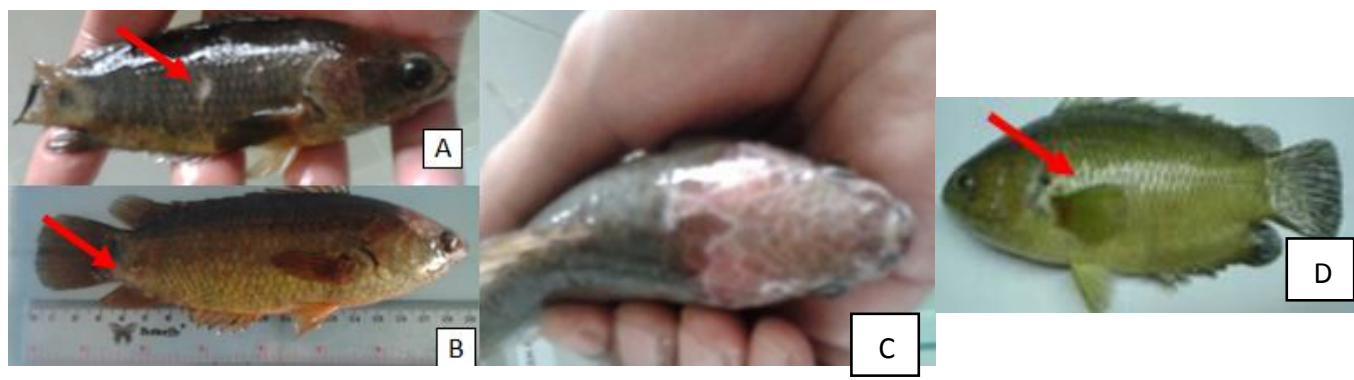

Figure 1. A: Fish are injured on the body surface, broken fins. B: fish injured at the base of the caudal fin. C: The fish are injured, loose scales on the head. D: normal fish. 
The fishes were transported in a simple etching with wet systems tend to have red spots, cutting, loosing scales on the surface of the body, operculum, and head. The fishes were also found to have prominent eyes (exoptalmia) and fin gripis. Pathologies can be caused by friction between a fish with another fish. It is known that these fishes have scales and fins that are hard and sharp, so they can cause injury easily to another fish when it is in a full freight container. The length of time also affects the transportion of intensity / frequency of fish rubbing. This allows getting more injury. Fish Market of Segiri just accommodated with a simple container during the sales process. there was also the triggers for the occurrence of injuries to the outside organs of the fish. It is caused by accommodation with high density without aeration and with a small amount of water. The observation of anatomical pathology of the outside organ showed that the transportion factor and storage of fish effected on anatomical pathology of Betok Fish marketed at the Segiri Market.

\section{Pathological Internal Organs}

Observation of organs in the anatomical pathology of Betok Fish originating from aquaculture / shelters and Market of Segiri is also performed. The Results are presented in table 3.

Betok Fishes taken from aquaculture pond are not getting changing in the anatomy of organs and outside organ. It indicates that the Betok is still in normal condition. It is only about $13 \%$ of the fishes that have abnormalities in the liver and kidneys, the visible changing is the presence of liver and kidney turned pale and became flaccid organ.

Most of the fishes are taken from the Market of Segiri in abnormality condition, especially in the internal organ, such as the liver became pale and as much as 53\% of the fishes suffered pathology in the liver, kidney, or both of them. The changes indicate that the transportion system of the Betok Fish come from cultivation pond / reservoir cause the fish gotstress or disturbance. The current container carriage conditions, lack of oxygen supply, the density in a freight container are very important for the fish health condition.

\section{Bacteria isolation}

Isolation of bacteria was done by doing isolation of some organs, such as eyes, heart, brain and kidneys. The result of observation appointed that there are several colonies of bacteria that grow on TSA media / NA better than an original fish and fish from Segiri Market. Several colonies looked round, white as milk and suburban colony. There are also colonies having yellow colour. Then, from aquaculture pond and Market of Segiri, it is found that there are four bacterial colonies with characteristic colony of yellow, white, red, and pale.

\section{Identification of Bacteria}

Identification results of bacteria is known to have four types of bacteria found on farmed tilapia and five types of bacteria that infect origin tilapia from Segiri Market. It is described in detail in Table 4.

Table 3. Pathology anatomy of the organ in the betok fish from aquaculture pond and market

\begin{tabular}{cccccccccccccccccc}
\hline $\begin{array}{c}\text { Change () } \\
\text { Internal } \\
\text { organ) }\end{array}$ & $\begin{array}{c}\text { Asal } \\
\text { Ikan }\end{array}$ & Sampel & $\mathbf{1}$ & $\mathbf{2}$ & $\mathbf{3}$ & $\mathbf{4}$ & $\mathbf{5}$ & $\mathbf{6}$ & $\mathbf{7}$ & $\mathbf{8}$ & $\mathbf{9}$ & $\mathbf{1 0}$ & $\mathbf{1 1}$ & $\mathbf{1 2}$ & $\mathbf{1 3}$ & $\mathbf{1 4}$ & $\mathbf{1 5}$ \\
\hline \multirow{2}{*}{ liver } & culture & - & - & - & - & - & + & - & - & - & - & - & - & - & - & - \\
& market & - & - & + & + & - & + & + & + & + & - & + & + & - & - & - \\
& culture & - & - & - & + & - & - & - & - & - & - & - & + & - & - & - \\
Spleen & market & - & - & + & + & - & - & + & + & + & - & + & + & - & - & -
\end{tabular}

\section{Description :}

+: Experiencing changes in shape, color and consistency

-: No change 
Tabel 4. Inventory of bacteria from betok fish

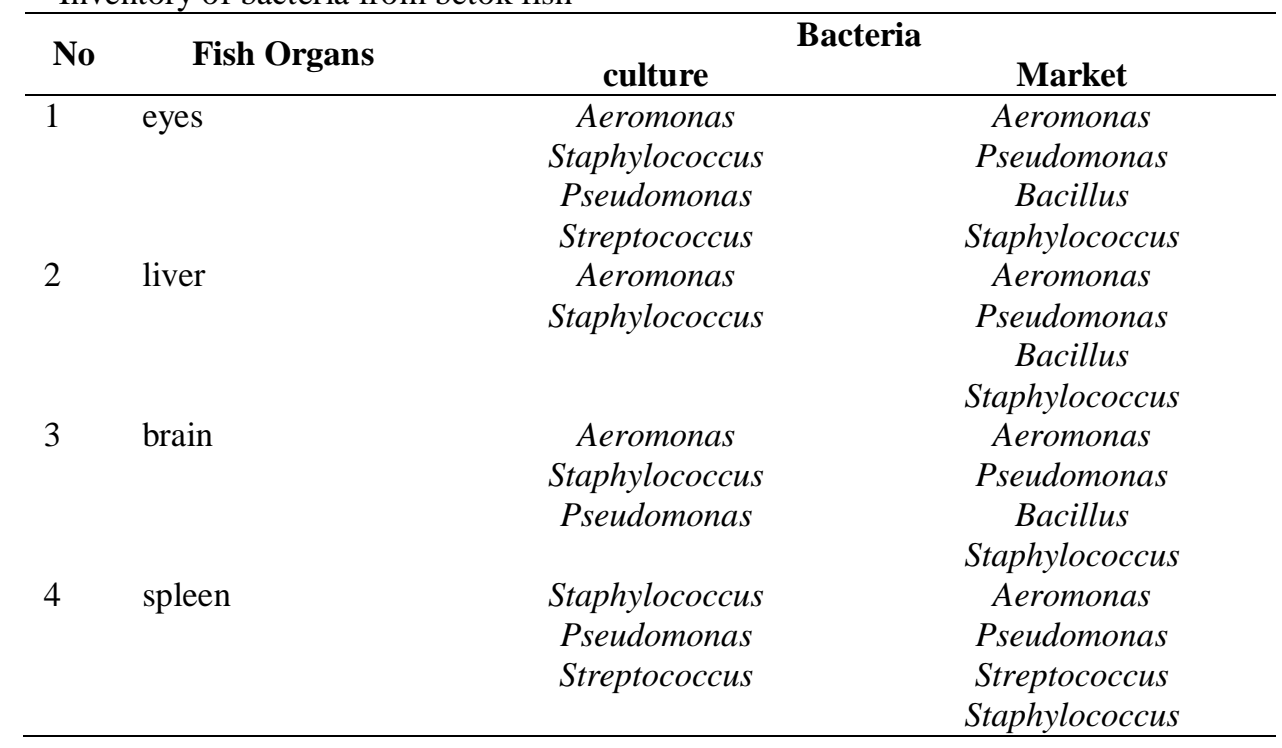

Results of the isolation and identification of bacteria from Betok Fish marketed in Segiri Market of Samarinda, it is known that there are five types of bacteria, namely: Aeromonas, Pseudomonas, Staphyllococcus, Streptococcus, and Basillus. The fifth type of bacteria is a bacterium that is commonly found in freshwater fish and many people reported the infection of fish farming (Austin and Austin, 2007). The presence of bacteria highly depends on environmental conditions and the condition of the fish itself. The transportion and storage system of fish plays a role in the increase of intensity and prevalence of bacterial infections in Betok Fish.

It is based on all of the observations, It can be concluded that there is a correlation between wet transportion undertaken to send the fish to the Market of Segiri and bacterial diseases that infects to the fishes. In addition, the transportion system is done with the high stocking density, lack of oxygen causes fish abnormalities in behavior, anatomic pathology, both in outside and internal organs as well as the types of pathogens, so it is necessary to transport engineering better with attention to stock density and the intake of oxygen during delivery.

\section{Reference}

Anderson, D.P. and A.K. Siwicki. 1995. Basic Haemotology and Serology for Fish Health Programs. Paper Presented in Second Symposium on Diseases in Asian Aquaculture "Aquatic Animal Health and the Environment". Phuket, Thailand. 25 $29^{\text {th }}$ October 1993. Pp. $185-202$.

Austin, B. and D.A. Austin. 2007. Bakterial fish pathogens. Fourth Edition. New York: Praxis Publishing Ltd. pp 552

Braxhall, P.C And K.W. Daisley. 1973. Routine haemotological methods for use with fish blood. Journal Fish Biology, 5:577-581.

Hardi, E.H., Sukenda, E. Harris, dan A.M. Lusiastuti. 2011. Karakteristik dan patogenisitas Streptococcus Agalactiae Tipe $\beta$-hemolitik dan Non-hemolitik pada Ikan Nila. Jurnal veteriner, Vol. 12,2: 152164

SNI [Standar Nasional Indonesia]. No. 7303 : 2009. Uji karakteristik bakteri Aeromonas hydrophila secara biokimia. Jakarta : Badan Standarisasi Nasional.

Wedemeyer, G.A. and W.T. Yasutake. 1977. Clinical methods for the assessement of the effect environmental stress on fish health. Technical Papers of The U.S. Fish and Wild field Service. US. Depart. of the Interior Fish and Wildlife Service, 89: 1-17. 